\title{
Optimization of Thermostable $\alpha$ - Amylase Production by Streptomyces erumpens MTCC 7317 in Solid-state Fermentation Using Cassava Fibrous Residue
}

\author{
Shaktimay Kar ${ }^{1}$, Tapan Kumar Datta ${ }^{2}$ and Ramesh Chandra Ray ${ }^{1 *}$ \\ ${ }^{1}$ Microbiology Laboratory; Central Tuber Crops Research Institute (Regional Centre); Bhubaneswar 751019, \\ Orissa - India. ${ }^{2}$ Teachers' Training Department, Panskura Banamali College, Midnapore - 721152, India
}

\begin{abstract}
Production of $\alpha$ - amylase under solid state fermentation by Streptomyces erumpens MTCC 7317 was investigated using cassava fibrous residue, one of the major solid waste released during extraction of starch from cassava (Manihot esculenta Crantz). Response surface methodology (RSM) was used to evaluate the effect of the main variables, i.e., incubation period $(60 \mathrm{~h})$, moisture holding capacity $(60 \%)$ and temperature $\left(50^{\circ} \mathrm{C}\right)$ on enzyme production by applying a full factorial Central Composite Design. Varying the inoculum concentration (5-25\%) of $\mathrm{S}$. erumpens showed that $15 \%$ inoculum $\left(\mathrm{v} / \mathrm{w}, 2.5 \times 10^{6} \mathrm{CFU} / \mathrm{ml}\right)$ was the optimum for $\alpha$-amylase production. Among the different nitrogen sources supplemented, beef extract was most suitable for enzyme production. The application of S. erumpens enzyme in liquefaction of soluble starch and cassava starch was studied. The maximum hydrolysis of soluble starch (85\%) and cassava starch (70\%) was obtained with the application of $5 \mathrm{ml}$ crude enzyme (17185 units) after 5 h of incubation.
\end{abstract}

Key words: $\alpha$ - amylase, cassava fibrous residue, optimization, response surface methodology, solid state fermentation

\section{INTRODUCTION}

Cassava (Manihot esculenta Crantz; Family, Euphorbiaceae) is considered an important source of food and dietary calories for a large population in tropical countries in Asia, Africa and Latin America. It contains $20-30 \%$ extractable starch depending on the varieties. In India, more than 1500 cottage and small scale industries crush over 5000 tonnes of cassava per day during harvest season (Edison et al., 2006). In the extraction of starch from cassava, fibrous residue, called as cassava fibrous residue (CFR) constitute about 15$20 \%$ by weight of cassava chips/ tubers processed, is retained on the sieves during the rasping process, which contain about $10-15 \%$ crude fiber and 55-65\% starch (on dry weight basis) (Ray, 2004; Jyothi et al., 2005). However, there is serious concern about the disposal of solid residue left after the large-scale extraction of starch from cassava. Due to its rich organic matter and low ash content (Pandey et al., 2000a,c), it can serve as an ideal substrate for microbial processes for the production of value added products, i.e., organic acid (Jyothi et al., 2005), ethanol and enzyme (Ray et al., 2008), etc.

Among the various extracellular thermostable enzymes, $\alpha$ - amylase ranks first in terms of commercial exploitation (Pandey et al., 2000a; Haki and Rakshit, 2003), particularly in starch

\footnotetext{
*Author for correspondence: rc_ray@ rediffmail.com
} 
processing industry. Industrially important enzymes have traditionally been obtained from submerged fermentation $(\mathrm{SmF})$ because of the ease of handling and greater control of environmental factors such as temperature and $\mathrm{pH}$. However, solid-state fermentation (SSF) constitutes an interesting alternative since the metabolites so produced are concentrated and purification procedures are less costly (Nigam and Singh, 1995; Pandey et al., 2000b). SSF process takes place in the absence and near absence of free water, thus being close to the natural environment to which microorganisms are adapted. SSF has numerous advantages including higher productivity and may be preferred to $\mathrm{SmF}$ because of simple technique, lower levels of catabolic repression and end-product inhibition, better product recovery and low waste water out put (Gangadharan et al., 2006). In the SSF process, the solid substrate not only supplies the nutrients to the cultures but also serves as an anchorage for the microbial cells.

Response Surface methodology (RSM) is an experimental strategy for seeking the optimum conditions for a multivariable system (He et al., 2004) and is used for optimization of culture conditions (Rao et al., 1993). RSM consists of a group of mathematical and statistical procedures that allows quick screening of large experimental domain and can be used to study relationships between one or more responses and a number of independent variables. RSM has been successfully applied for the production of primary and secondary metabolites (Shirai et al., 2001; Boyaci, 2005), amino acid (Xiong et al., 2005), ethanol (Carvalho et al., 2003) and enzymes (Rao and Satyanarayana, 2003).

In a previous study, a moderately thermostable $\alpha$ - amylase producing actinomycete strain, Streptomyces erumpens MTCC 7317 was isolated from a brick kiln soil (Kar and Ray, 2008). The strain showed the optimum incubation period, $\mathrm{pH}$ and temperature for $\alpha$-amylase production in $\mathrm{SmF}$ as $36 \mathrm{~h}, 6.0$ and $50^{\circ} \mathrm{C}$, respectively and the molecular mass of the enzyme was $54.5 \mathrm{kDa}$. The purpose of the present investigation was to study the $\alpha$-amylase production by $S$. erumpens MTCC 7317 in SSF using CFR as the substrate and optimization of the fermentation parameters (incubation period, moisture holding capacity and temperature) by applying RSM.

\section{MATERIALS AND METHODS}

\section{Microorganism}

The S. erumpens MTCC 7317 was isolated earlier from a brick kiln soil near by Bhubaneswar, India. The culture was maintained on starch- beef extract (soluble starch, 1\%; beef extract, $1 \% ; \mathrm{MgSO}_{4}$, $0.01 \%$; glycerol, $0.02 \%$; agar, $2 \%$; $\mathrm{pH}, 6.0$ ) agar slants at $4^{\circ} \mathrm{C}$.

\section{Cassava fibrous residue (CFR)}

CFR [(g/100g dry residue); moisture, 11.2; starch, 63.0; crude fibre, 10.8; crude protein, 0.9 and total ash, 1.2] (Ray et al., 2008) was used as solid substrate (support and nutrient source) for SSF. CFR was collected during starch extraction (February-March 2007) from cassava using the mobile starch extraction plant (Edison et al., 2006). Because of its high water and starch content, the residues were de-watered, sun-dried for 6-8 days and then oven - dried at $80^{\circ} \mathrm{C}$ for 24 h. The dried CFR was stored in air-tight container until required.

Optimization of incubation period, moisture holding capacity and temperature by applying RSM

The characterization of different factors for $\alpha$ - amylase production was optimized by applying the RSM. The statistical model was obtained using the Central Composite Design (CCD) with three independent variables [incubation period (A), moisture holding capacity (B) and temperature (C)]. Each factor in this design was studied at five different levels (Table 1). A set of 20 experiments was performed. All the variables were taken at a central coded value considered as zero. The minimum and maximum ranges of variables were used. The full experimental plan with respect to their values in coded form is shown in Table 2 . Upon completion of the experiments, the average of $\alpha$-amylase production was taken as the dependent variable or response.

\section{Statistical analysis and modeling}

The data obtained from the RSM on $\alpha$-amylase production was subjected to the analysis of variance (ANOVA). The results of RSM were used to fit a second order polynomial equation (1) as it represented the behavior of such a system more appropriately. 
$Y=\beta_{0}+\beta_{1} A+\beta_{2} B+\beta_{3} C+\beta_{1} \beta_{1} A^{2}+\beta_{2} \beta_{2} B^{2}$

$+\beta_{3} \beta_{3} C^{2}+\beta_{1} \beta_{2} A B+\beta_{1} \beta_{3} A C+\beta_{2} \beta_{3} B C$

Where $\mathrm{Y}$ was response variable, $\beta_{0}$ was intercept, $\beta_{1}, \beta_{2}$ and $\beta_{3}$ were linear coefficients, $\beta_{1,1}, \beta_{2,2}$ and $\beta_{3,3}$ were squared coefficient, $\beta_{1,2}, \beta_{1,3}$ and $\beta_{2,3}$ were interaction coefficient and $\mathrm{A}, \mathrm{B}, \mathrm{C}, \mathrm{A}^{2}, \mathrm{~B}^{2}$, $\mathrm{C}^{2}, \mathrm{AB}, \mathrm{AC}$ and $\mathrm{BC}$ were the level of independent variables. Statistical significance of the model equation was determined by Fisher's test value, and the production of variance explained by the model was given by the multiple coefficient of determination, $R$ squired $\left(\mathrm{R}^{2}\right)$ value. Design Expert (ver, 7.0; STATEASE INC; Minneapolis, MN, USA) was used in this investigation.

Table 1 -Range of the values for the response surface methodology.

\begin{tabular}{lccccc}
\hline Independent variables & \multicolumn{5}{c}{ Coded Factor Levels } \\
\cline { 2 - 6 } & $-\alpha$ & -1 & 0 & +1 & $+\alpha$ \\
Incubation period $(\mathrm{h})$ & 24.48 & 36 & 60 & 84 & 141.12 \\
Moisture holding capacity $(\%)$ & 20.4 & 30 & 60 & 90 & 151.2 \\
Temperature $\left({ }^{\circ} \mathrm{C}\right)$ & 20.4 & 30 & 50 & 70 & 151.2 \\
\hline
\end{tabular}

\section{Effect of incubation period on enzyme production}

The inoculum was prepared in soluble starch-beef extract broth by transferring a loop full of $\mathrm{S}$. erumpens from a stock culture and incubating at 500C and $120 \mathrm{rpm}$ for $24 \mathrm{~h}$ in an orbital incubator shaker (Remi Pvt. Ltd, Bombay, India). CFR (20 g) was taken in Roux bottles (132 mm x $275 \mathrm{~mm}$ ), moistened with $27 \mathrm{ml}$ of distilled water containing $1 \%$ beef extract and $0.02 \%$ glycerol to provide $60 \%$ moisture holding capacity (MHC) and the contents were mixed thoroughly. The bottles were autoclaved at $15 \mathrm{lb}$ pressure for $30 \mathrm{~min}$. After cooling at room temperature, $(30 \pm 20 \mathrm{C})$ these were inoculated with $15 \%(\mathrm{v} / \mathrm{w})$ (equivalent to $2.5 \times 106$ $\mathrm{CFU} / \mathrm{ml}$ ) inoculum and incubated under static condition at $500 \mathrm{C}$ for $84 \mathrm{~h}$. Triplicate bottles were maintained for each treatment. The contents in the bottle were periodically mixed by gentle tapping. At interval of $12 \mathrm{~h}$, the enzyme was extracted with $25 \mathrm{ml}$ of distilled water (1:2 [CFR: Water] ratio) and squeezed through a wet cheese cloth. The pooled enzyme extract was centrifuged at 8000 rpm for $20 \mathrm{~min}$ in refrigerated centrifuge (Remi India Pvt Ltd, Bombay, India) and the clear supernatant was used for enzyme assay.

\section{Effect of moisture holding capacity on enzyme production}

The influence of MHC on the enzyme titer was evaluated by varying the moisture content of the substrate from 30 to $90 \%$ MHC and the samples were incubated for $60 \mathrm{~h}$ at $500 \mathrm{C}$.

Effect of temperature and inoculum volume and nitrogen sources on enzyme production.
The effect of temperature and inoculum volume was studied by growing the culture at different temperatures $\left(30-70^{\circ} \mathrm{C}\right)$ and inoculating with $5-$ $25 \%$ inoculum. Beef extract $(1 \%)$ present in the basal medium was substituted with equal amount of different organic and inorganic nitrogen source. The cell population in the inoculum was counted using a hemocytometer. Data were given as a mean of three replicates.

\section{Thin-layer chromatographic analysis}

The products liberated by the action of amylase on starch were identified by spotting the starch digest and standard sugars (glucose and maltose) on a silica gel plate activated at $80^{\circ} \mathrm{C}$ for $30 \mathrm{~min}$. The plates were developed in butanol: ethanol: water (50:30:20) and dried overnight at $32 \pm 2^{\circ} \mathrm{C}$. The individual sugar(s) were visualized with acetonesilver nitrate solution $(0.1 \mathrm{ml}$ saturated solution of $\mathrm{AgNO}_{3}$ in $20 \mathrm{ml}$ of acetone).

\section{Amylase assay}

The amylase assay was based on the reduction in blue colour intensity resulting from the enzymatic hydrolysis of starch and formation of starch-iodine complex (Swain et al., 2006). The reaction mixture consisted of $0.2 \mathrm{ml}$ enzyme (cell free supernatant), $0.25 \mathrm{ml}$ of $0.1 \%$ starch solution and $0.5 \mathrm{ml}$ of phosphate buffer (0.1 M, pH 6.0) incubated at $50^{\circ} \mathrm{C}$ for $10 \mathrm{~min}$. The reaction was stopped by adding $0.25 \mathrm{ml}$ of $0.1 \mathrm{~N} \mathrm{HCl}$ and the colour was developed by adding $0.25 \mathrm{ml}$ of $\mathrm{I} / \mathrm{KI}$ solution ( $2 \%$ $\mathrm{KI}$ in $0.2 \% \mathrm{I}$ ). The optical density (OD) of the blue colour solution was determined using a UV-Vis Spectrophotometer (Model no CE 7250, Cecil 
Instrument, UK) at $690 \mathrm{~nm}$. One unit of enzyme activity was defined as the quantity of enzyme that resulted in $0.01 \%$ reduction of blue colour intensity of starch- iodine solution at $50^{\circ} \mathrm{C}$ in one minute per ml (Swain et al., 2006). In SSF, units of enzyme activity were calculated as units per gram of dry substrate (gds).

\section{Rate of hydrolysis of starch}

A $2 \%(\mathrm{w} / \mathrm{v})$ of soluble starch and cassava starch were incubated with 2-6 $\mathrm{ml}$ of $S$. erumpens crude enzyme obtained from SSF at $50^{\circ} \mathrm{C}$ in an incubator. The degradation of starch was evaluated at one hour interval up to $6 \mathrm{~h}$.

\section{RESULTS}

Using thin-layer chromatographic analysis, it was ascertained that the amylase produced by the S. erumpens was $\alpha$ - amylase owing to the presence of two important sugars (i.e., glucose and maltose) as the end-product of starch hydrolysis (results not shown). Amongst the nitrogen sources, organic nitrogen supported higher $\alpha$ - amylase secretion in comparison with inorganic nitrogen sources. Maximum amylase production $(3437.5 \pm 105.0)$ was obtained when beef extract was supplemented as the nitrogen source. Other nitrogen sources (1\%) resulted in enzyme production (in units) as follows: ammonium acetate, $1312.5 \pm 105.0$; ammonium chloride, $932.5 \pm 95.0$; ammonium nitrate, $1781.2 \pm 110.0$; ammonium sulphate, $1231.5 \pm 110.0$; asparagines $291.3 \pm 123.0$; potassium nitrate, $1678.8 \pm 120.0$; urea, $937.5 \pm$ 115.0; casein, $2850.0 \pm 121.0$; peptone, $3245.0 \pm$ 101.0 and yeast extract, $3175.0 \pm 105.0$. Varying inoculum concentrations (5-25\%) of S. erumpens cell during the fermentation showed that $15 \%$ (v/w; $2.5 \times 10^{6} \mathrm{CFU} / \mathrm{ml}$ ) inoculum was optimum for enzyme production (data not shown).

The results of CCD experiments for studying the effect of three independent fermentation variables (incubation period, MHC and temperature) along with the mean predicted and observed responses are presented in Table 2. The regression equations obtained after the ANOVA gave the level of $\alpha$ amylase production as a function of the initial values of incubation period, MHC and temperature. The final response equation that represented a suitable model for $\alpha$-amylase production was as below:

$$
\begin{aligned}
& \mathrm{Y}=57.97+1.78 \mathrm{~A}-0.17 \mathrm{~B}+2.48 \mathrm{C}-0.89 \mathrm{~A}^{2} \\
& -2.49 \mathrm{~B}^{2}-5.78 \mathrm{C}^{2}+1.12 \mathrm{AB}+2.28 \mathrm{AC}+ \\
& 1.82 \mathrm{BC}
\end{aligned}
$$

Where $\mathrm{Y}$ was enzyme production, $\mathrm{A}$ was incubation period (hr), B was MHC (\%) and $\mathrm{C}$ was temperature $\left({ }^{\circ} \mathrm{C}\right)$.

The coefficient of determination $\left(\mathrm{R}^{2}\right)$ was calculated as 0.9505 for $\alpha$-amylase production (Table 3), indicating that the statistical model could explain $95.05 \%$ of variability in the response. The $R^{2}$ value is always between 0 and 1 . The closer the value of $\mathrm{R}^{2}$ to 1.0 , the stronger the model and the better it predicts the response (Swain and Ray, 2007). An adequate precision of 15.105 for $\alpha$ - amylase production was recorded. The predicted $\mathrm{R}^{2}$ of 0.6357 was in reasonable agreement with the adjusted $\mathrm{R}^{2}$ of 0.9059 . This indicated a good agreement between the experimental and predicted value for $\alpha$-amylase production. The model $\mathrm{F}$ - value of 21.32 and values of prob $>\mathrm{F}(<0.05)$ indicated that the model terms were significant. For $\alpha$ - amylase production $\mathrm{A}, \mathrm{C}, \mathrm{AC}, \mathrm{BC}, \mathrm{B}^{2}$ and $\mathrm{C}^{2}$ were significant model. The "lack of fit F- value" of 16.97 implied that the "lack of fit" was significant.

The Response surface was generated by plotting the response ( $\alpha$-amylase production) on the z-axis against any two independent variables while keeping the other independent variable at their zero level. Therefore, three response surfaces were obtained by considering all the possible combinations. 
Table 2 -Experimental design and result of CCD of response surface methodology.

\begin{tabular}{cccccc}
\hline Std & $\begin{array}{c}\text { A: Incubation } \\
\text { period }(\mathbf{h})\end{array}$ & $\begin{array}{c}\text { B: Moisture } \\
\text { holding capacity }(\boldsymbol{\%})\end{array}$ & $\begin{array}{c}\text { C: Temperature } \\
\left({ }^{\circ} \mathbf{C}\right)\end{array}$ & \multicolumn{2}{c}{ Enzyme production (U/gds) } \\
\hline & & & & Predicted & Experimental \\
\cline { 3 - 5 } 1 & -1 & -1 & -1 & 2556.51 & 2588.33 \\
2 & 1 & -1 & -1 & 2216.11 & 2410.00 \\
3 & -1 & 1 & -1 & 1919.83 & 2130.00 \\
4 & 1 & 1 & -1 & 2064.93 & 2160.00 \\
5 & -1 & -1 & 1 & 2153.04 & 2190.00 \\
6 & 1 & -1 & 1 & 2758.15 & 2680.00 \\
7 & -1 & 1 & 1 & 2266.86 & 2205.00 \\
8 & 1 & 1 & 1 & 3357.46 & 3345.00 \\
9 & $-\alpha$ & 0 & 0 & 3065.08 & 2670.00 \\
10 & $+\alpha$ & 0 & 0 & 3440.19 & 3245.00 \\
11 & 0 & $-\alpha$ & 0 & 3092.45 & 2541.00 \\
12 & 0 & $+\alpha$ & 0 & 3073.77 & 2415.00 \\
13 & 0 & 0 & $-\alpha$ & 2579.59 & 1150.00 \\
14 & 0 & 0 & $+\alpha$ & 3024.12 & 2215.00 \\
15 & 0 & 0 & 0 & 3362.99 & 3457.67 \\
16 & 0 & 0 & 0 & 3362.99 & 3427.00 \\
17 & 0 & 0 & 0 & 3362.99 & 3397.00 \\
18 & 0 & 0 & 0 & 3362.99 & 3427.00 \\
19 & 0 & 0 & 0 & 3362.99 & 3387.00 \\
20 & 0 & 0 & 0 & 3362.99 & 3227.00 \\
\hline
\end{tabular}

Table 3 -ANOVA for $\alpha$ - amylase production in solid state fermentation.

\begin{tabular}{lccccc}
\hline Source & Sum of Squares & Degree of freedom & Mean Square & F-Value & p-value \\
\hline Model & 740.65 & 9 & 82.29 & 21.32 & 0.0001 \\
Pure Error & 2.15 & 5 & 0.43 & & \\
Total & 779.25 & 19 & & & \\
\hline
\end{tabular}

$\mathrm{R}^{2}=0.9505$

Adjusted $\mathrm{R}^{2=} 0.9059$

Predicted $\mathrm{R}^{2}=0.6357$

Adequate Precision $=15.105$

Lack of Fit F- value $=16.97$

Fig. 1A depicts three dimensional diagram and a contour plot of calculated response surface from the interaction between incubation period and moisture holding capacity while keeping the other variable (temperature) at ' 0 ' level. A linear increase in $\alpha$-amylase production was observed when incubation period was increased up to $60 \mathrm{~h}$, and there after, it declined. When the level of MHC was increased from 30 to $60 \%$, a linear increased in $\alpha$-amylase production was recorded. At the ' 0 ' level of MHC, the response between the incubation period and temperature indicated that a higher temperature $\left(50^{\circ} \mathrm{C}\right)$ was optimum (Fig. 1B) with $60 \mathrm{~h}$ incubation period for $\alpha$-amylase production. The response surface was mainly used to find out the optima of the variables for which the response was maximized. An interaction between the remaining two parameters (MHC and temperature) (Fig. 1C) suggested a little difference with the earlier responses. Thus, the incubation period $(60 \mathrm{~h}), \mathrm{MHC}(60 \%)$ and temperature $\left(50^{\circ} \mathrm{C}\right)$ were adequate for attaining the maximum enzyme production ( $3457.67 \mathrm{U} / \mathrm{gds}$ ) as shown in Table 2. 


\section{A}

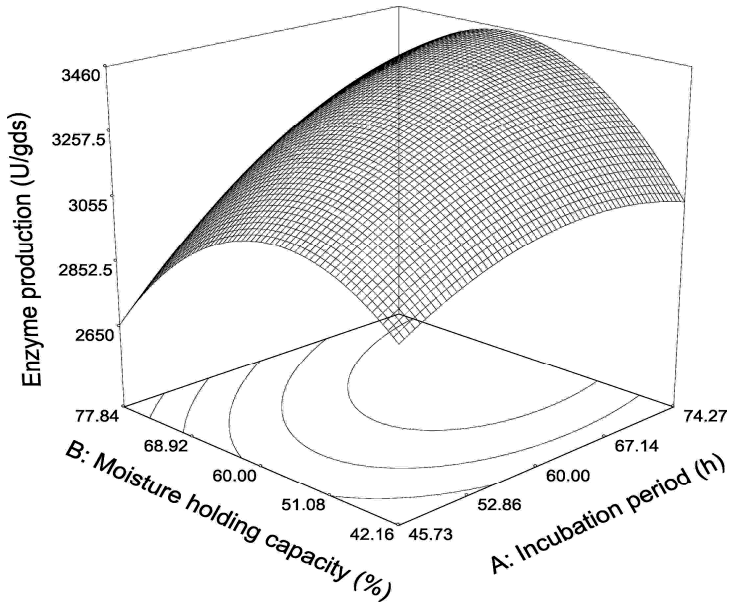

B

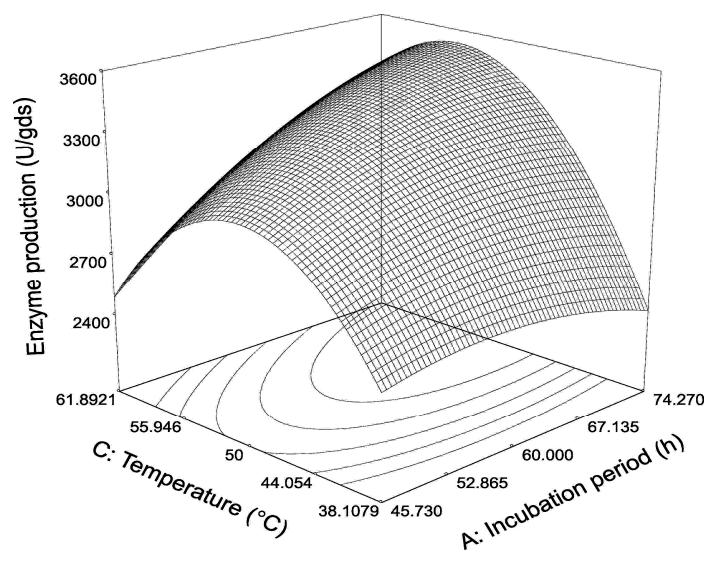

C

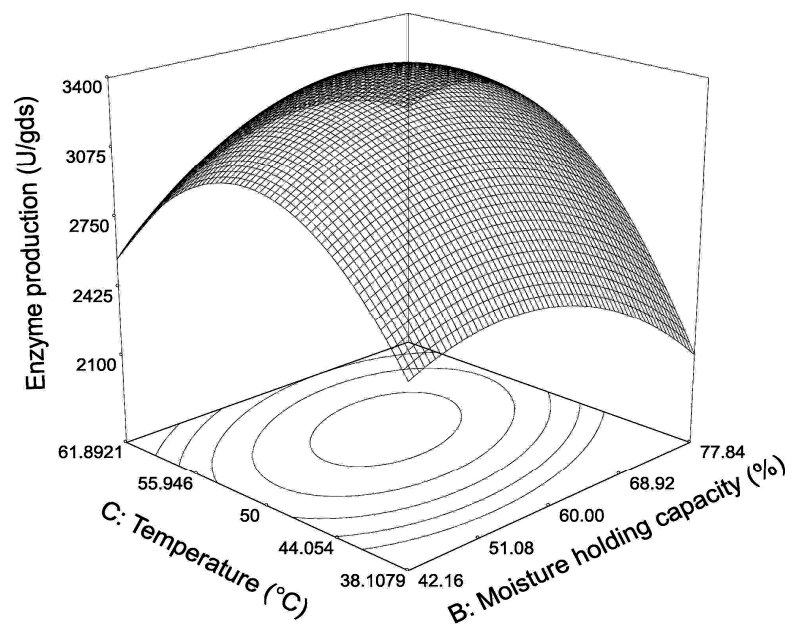

Figure 1 - Statistical optimization of enzyme production using RSM, (A) incubation period and moisture holding capacity; (B) incubation period and temperature and (C) temperature and moisture holding capacity.

\section{Validation of model}

Validation was carried out under the conditions predicted by the model. The experimental values were very close to the predicted values; hence, the model was successfully validated. The validation of the statistical model and regression equation was performed by taking A $(60 \mathrm{~h}), \mathrm{B}(60 \%)$ and C $\left(50^{\circ} \mathrm{C}\right)$ in the experiment. The predicted response for $\alpha$-amylase production was $3362.99 \mathrm{U} / \mathrm{gds}$, while the actual (experimental) response was $3457.67 \mathrm{U} / \mathrm{gds}$, thus proving the validity.

\section{Application}

The application of $S$. erumpens crude enzyme for hydrolysis of soluble starch and cassava starch is shown in Fig. 2. The rate of hydrolysis of starch increased with increase in enzyme concentration $(2-6 \mathrm{ml})$ as well as incubation period (1- $6 \mathrm{~h}$ ). With application of $5 \mathrm{ml}$ crude enzyme (17185 units) for $5 \mathrm{~h}$, there were 85 and $70 \%$ hydrolysis of soluble starch and cassava starch, respectively. 


\section{DISCUSSION}

In recent years, the application of the agroindustrial residue (i.e., CFR, sugar cane bagasse, sugar beet pulp, apple pomace, wheat bran, etc) has provided an alternative way to replace the pure and costly raw materials. The use of such materials would help to solve many environmental hazards (John et al., 2006). Several processes have been developed that utilize these as raw materials, including CFR for the production of value added products such as ethanol, enzymes, organic acids, etc (Pandey et al., 2000b).

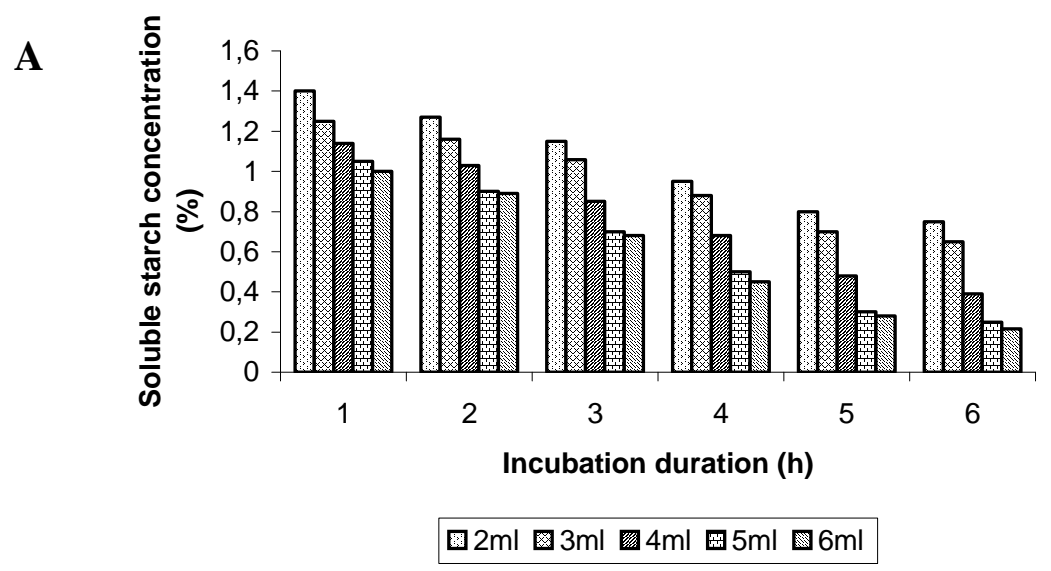

B

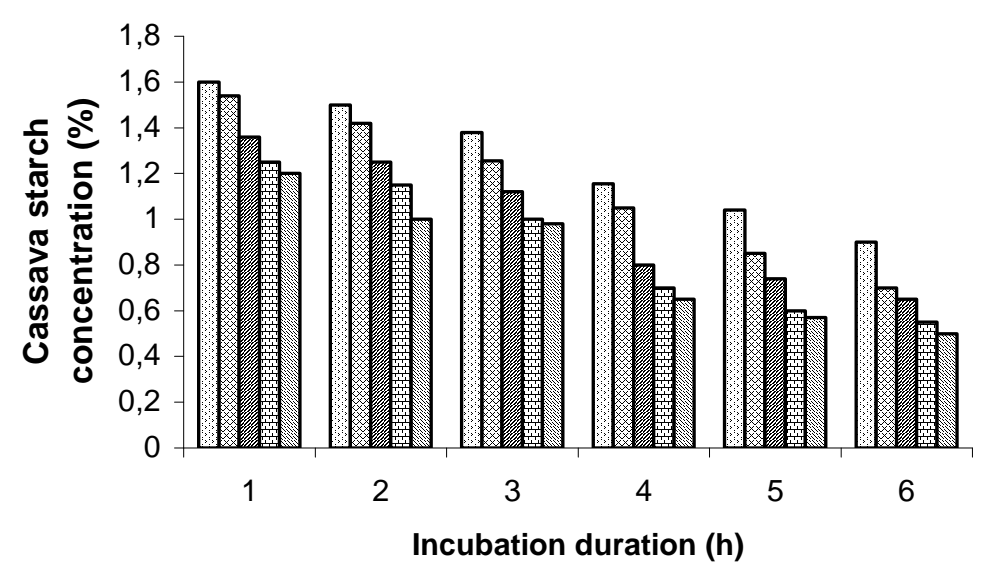

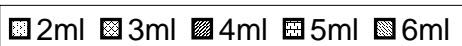

Figure 2 - Hydrolysis of soluble starch (A) and cassava starch (B) by different concentration (2-6 ml) of $\alpha$ - amylase from $S$. erumpens.

The RSM used in this investigation suggested the importance of various fermentation parameters at different levels. A high similarity was observed between the predicted and experimental results, which reflected the accuracy and applicability of the RSM to optimize the process for enzyme production. A 1.25- 2.0 fold increase in $\alpha$-amylase production was reported in Bacillus circulans GRS
313 (Dey et al., 2001) and Geobacillus thermooleovorans (Rao and Satyanarayana, 2003) by using RSM; carbon (glucose) and nitrogen (soy bean meal or yeast extract) sources significantly influenced the enzyme production. In this investigation, incubation period $(60 \mathrm{~h}), \mathrm{MHC}$ $(60 \%)$ and temperature $\left(50^{\circ} \mathrm{C}\right)$ were the major factors that gave higher enzyme yield. The 
decrease in enzyme yield after the optimum incubation period $(60 \mathrm{~h})$ might be because of the denaturation or decomposition of $\alpha$-amylase due to interaction with other components in the culture medium (Gangadharan et al., 2006) and loss of moisture with prolonged incubation at $50^{\circ} \mathrm{C}$ (Baysal et al., 2003). In contrast, $\alpha$-amylase production from Streptomyces rimosus was reported at $180 \mathrm{~h}$ incubation using sweet potato residue as the substrate (Yang and Wang, 1999).

Moisture holding capacity is one of the most important factor in SSF that influences the growth of the organism and thereby enzyme production (Babu and Satyanarayana, 1995; Baysal et al., 2003). MHC (60\%) was found to be optimum for $\alpha$-amylase production in the present study in commitant with some other reports (Yang and Wang, 1999; Gangadharan et al., 2006). Beyond $60 \%$ MHC, the activity was found to decline. The decline might be attributed to poor porosity, lower oxygen transfer, poor aeration and adsorption of enzyme to the substrate particle (Pandey et al., 2000b; Ray et al., 2006).

\section{CONCLUSION}

The result obtained in the present study indicated that $S$. erumpens MTCC 7317 could be a potential actinomycete strain for $\alpha$-amylase production in SSF using CFR as the substrate. The RSM allowed the optimization of cultural parameters such as incubation period $(60 \mathrm{~h})$, MHC $(60 \%)$ and temperature $\left(50^{\circ} \mathrm{C}\right)$ for attaining the high yields of $\alpha$-amylase.

\section{ACKNOWLEDGEMENTS}

The authors thank the Director of this Institute for providing facilities.

\section{REFERENCES}

Babu, K. R. and Satyanarayana, T. (1995), $\square$-amylase production by thermophilic Bacillus coagulans in solid state fermentation. Process Biochemistry, 30, 305-309.
Baysal, Z.; Uyar, F. and Aytekin, C. (2003), Solid-state fermentation for production of $\alpha$ - amylase by a thermotolorant Bacillus subtilis from hot spring water. Process Biochemistry, 38, 1665-1668.

Boyaci, I. H. (2005), A new approach of determination of enzyme kinetic constants using response surface methodology. Biochemical Engineering Journal, 25, 55-62.

Carvalho, J. C. M.; Vitolo, M.; Sato, S. and Aquarone, E. (2003), Ethanol production by Saccharomyces cerevisiae grown in sugarcane blackstrap molasses through a feed batch process: optimization by response surface methodology. Applied Biochemistry and Biotechnology, 110, 151-164.

Dey, G.; Mitra, A.; Banerjee, R. and Matri, B. R. (2001), Enhanced production of alpha amylase by optimization of nutritional constituents using response surface methodology. Biochemical Engineering Journal, 7, 227-231.

Edison, S.; Anantharaman, M. and Srinivas, T. (2006), Status of cassava in India - an overall view. Tech Bull Ser, Central Tuber Crops research Institute, Thiruvanathapuram, India, 46, 79.

Gangadharan, D.; Sivaramakrishnan, S.; Nampoothiri, K. M. and Pandey, A. (2006), Solid culturing of Bacillus amyloliquefaciens for alpha amylase production. Food Technology and Biotechnology, 44, 269-274.

Haki, G. D. and Rakshit, S. K. (2003), Developments in industrially important thermostable enzymesReview. Bioresource Technology, 89, 17-34.

He, G. Q.; Kong, Q. and Ding, L. X. (2004), Response surface methodology for optimizing the fermentation medium of Clostridium butyricum. Letters in Applied Microbiology, 39, 363-368.

John, R. P.; Nampoothiri, K. M. and Pandey, A. (2006), Solid state fermentation for L- lactic acid production from agro- wastes using Lactobacillus delbrueckii. Process Biochemistry, 41, 759-763.

Jyothi, A. N.; Sasikiran, K.; Nambisan, B. and Balagopalan, C. (2005), Optimization of glutamic acid production from starch factory residue using Brevibacterium divaricatum. Process Biochemistry, 40, 3576-3579.

Kar, S. and Ray, R. C. (2008), Partial characterization and optimization of extracellular thermostable $\mathrm{Ca}^{2+}$ inhibited $\alpha$-amylase production by Streptomyces erumpens MTCC 7317. Journal of Scientific and Industrial Research, 67, 58-64.

Nigam, P. and Singh, D. (1995), Enzyme and microbial systems involved in starch processing. Enzyme and Microbial Technology, 17, 770-778. 
Pandey, A.; Nigam, P.; Soccol, C. R.; Soccol, V. T.; Singh, D. and Mohan, R. (2000c), Advances in microbial amylase. Biotechnology and Applied Biochemistry, 31, 135-152.

Pandey, A.; Soccol, C. R. and Mitchell, W. (2000b), New development in solid state fermentation: I.bioprocess and products. Process Biochemistry, 35, 1153-1169.

Pandey, A.; Soccol, C. R.; Nigam, P.; Soccol, V. T.; Vandenberghe, P. S. L.and Mohan, R. (2000a), Biotechnological potential of agro-industrial residues, II.- cassava bagasse. Bioresource Technology, 74, 8187.

Rao, J. L. M. and Satyanarayana, T. (2003), Statistical optimization of a high maltose-forming, hyperthermostable and $\mathrm{Ca}^{2+}$-independent $\alpha$ - amylase production by an extreme thermophile Geobacillus thermooleovorans using response surface methodology. Journal of Applied Microbiology, 95, 712-718.

Rao, P. V.; Jayaraman, K. and Lakshmanan, C. M. (1993), Production of lipase by Candida rugosa in solid-state fermentation, medium: optimization and effect of aeration. Process Biochemistry, 28, 391-395.

Ray, R. C. (2004), Extracellular amylase(s) production by fungi Botryodiplodia theobromae and Rhizopus oryzae grown on cassava starch residue. Journal of Environmental Biology, 25, 89-495.

Ray, R. C.; Mohapatra, S.; Panda, S. and Kar, S. (2008), Solid substrate fermentation of cassava fibrous residue for production of $\alpha$ - amylase, lactic acid and ethanol. Journal of Envronmental Biology, 29, 111-115.

Ray, R. C.; Sahoo, A. K.; Asana, K. and Tomita F. (2006), Microbial processing of agricultural residues for production of food, feed and food-additives. In: Microbial Biotechnology in Agriculture and Aquaculture, Vol. 2, ed. R. C. Ray. New Hampshire, Science Publishers, Inc, Enfield, pp. 511- 552.

Shirai, K.; Guerrero, I.; Huerta, S.; Saucedo, G.; Castillo, A.; Gorzalez, R. O. and Hall, G. M. (2001), Effect of initial glucose concentration and inoculum level of lactic acid bacteria in shrimp waste ensilation. Enzyme and Microbial Technology, 28, 446-452.

Swain, M. R.; Kar, S.; Padmaja, G. and Ray, R. C. (2006), Partial characterization and optimization of production of extracellular $\alpha$-amylase from Bacillus subtilis isolated from culturable cowdung microflora. Polish Journal of Microbiology, 55, 289-296.

Swain, M. R. and Ray, R. C. (2007), Alpha amylase production by Bacillus subtilis CM3 in solid state fermentation using cassava fibrous residue. Journal of Basic Microbiology, 47, 417-425.

Xiong, C.; Shouwen, C.; Ming, S. and Ziniu, Y. (2005), Medium optimization by response surface methodology for poly-Y- glutamic acid production using dairy manure as the basis of a solid substrate. Applied Microbiology and Biotechnology, 69, 390396.

Yang, S. S. and Wang, J. Y. (1999), Protease and amylase production of Streptomyces rimosus in submerged and solid state cultivations. Botanical Bulletin of Academia Sinica, 40, 259-265.

Received: October 30, 2007; Revised: August 18, 2008; Accepted: September 02, 2009. 